\title{
Injection Irrigation Method and its use for Watering
}

\author{
Orahbai Z. Zubairov, Mukhtarbek Zh. Nusipbekov, Kanat K. Anuarbekov, \\ Madina S. Nabiollina and Roza K. Makhambetova
}

Kazakh National Agrarian University, 8 Abay Street, Almaty, 050000, Republic of Kazakhstan.

DOI: http://dx.doi.org/10.13005/bbra/1946

(Received: 30 September 2015; accepted: 06 November 2015)

The article proposes a new method for plants watering that allows carrying out periodic watering and saving up to $\mathbf{8 0 - 8 6 \%}$ of irrigation water. The article presents the findings of field studies on the application of proposed method in relation to watering of tomato and corn under the conditions of Kazakhstan.

Key words: Injection irrigation, xylem, feeder unit, osmotic pressure, low pressure, suction, evaporation, transpiration, injection needle, injection, drip irrigation, filling tank.

Yearly increasing scarcity of irrigation water in the Republic of Kazakhstan under the market conditions dictates the need for its rational and economical use. In this regard, the development and implementation of methods and irrigation techniques, providing a uniform distribution of water over the irrigated field, the irrigation process automation, increasing productivity and reducing losses of water through filtration, are challenging for the areas of irrigated agriculture.

Today is the time of transition from the irrigation of "soil" to irrigation of "plants". In this regard we have received inventor's certificate on injection irrigation method [AC 22126], as well as provisional applications for patents of the Republic of Kazakhstan (RK) for several alternate injection irrigation systems ${ }^{1}$.

The novelty of this development is that it allows supplying irrigation water directly into the xylem of plants.

In this case supplied water is consumed

* To whom all correspondence should be addressed. only on transpiration. Water saving is up to $86 \%$. The implementation of this method will allow farmers to create an autonomous irrigation system on small areas without the construction of costly canals, hydraulic engineering structures, pumping stations and other elements of the irrigation system $^{2,3}$.

Theoretical and experimental studies of recent years conducted by ameliorators and physiologists have revealed the fact of achieving the biological optimum of crops at approaching the intensity of water supply to the intensity of consumptive water use $\mathrm{e}^{4,5}$.

When supplying water in the amount equal or close to the transpiration ability of the plant, water does not affect the plant's growth and development. To bring the rate of water supply of the plants to their consumptive water use, large role is played by irrigation technique ${ }^{6,7}$.

Water supplied to the field, which is occupied by agricultural cropper, is lost to evaporation consisting of three components: evaporation from the soil, transpiration of plants, and evaporation of natural and artificial precipitation that fell on vegetative organs during the irrigation ${ }^{8,9}$. In reclamation practices these 
components are not determined separately due to the complexity. Therefore the moisture use is measured by total value. This approach, in our opinion, is quite inaccurate, because just a small portion of water out of its total amount passes through the plant's body during the transpiration, while the other portion of water is used ineffectively ${ }^{10,11}$.

These days our farmers, when watering farmland, supply each planting hectare with 3,000$10,000 \mathrm{~m}^{3}$ of water. At that, about $85-90 \%$ of water is consumed unfruitfully. Thus, today the problem of reducing or complete eliminating of water loss is a pressing issue ${ }^{12}$.

Irrigation technique should insure water supply in the amount just needed for plant's transpiration. At that, the idea raises to supply water directly to the plant, bypassing the soil. To this end we draw attention to the mechanism of water supply into a plant cell. During the stages of plant's growth and development two water pumping systems supply the plant with water the roots, which are called the lower end engine, and suction of the water by leaves that is called upper end engine. Both engines operate in a similar way and can replace or supplement each other. Consequently, the water exchange in the plant consists of water intake into the plant through root hairs, its flow through the cells, and evaporation through the foliage ${ }^{13,14}$.

In contemporary conditions of water use, farmers, peasants and other forms of economies are not happy with the fact that using natural water for irrigation, i.e. when water transfers into the soil and air moisture, a huge amount of water is wasted useless. Water must be fed directly into the plant in accordance with its requirement in moisture, while other water use should be reduced to zero. Within this framework, the engineering devices which supply water to plants play the most important role ${ }^{15,16}$.

\section{Irrigation technique}

In this respect, injection irrigation technique is an innovative avenue. Based on the research conducted (2001-2009) we have developed the main components of the injection irrigation system, which includes: feeder unit, transmission pipeline made of rubber hoses, emitter lateral, and nozzles (needles) for water injection (Fig. 1)

The main component of the system is the feeder unit (Fig.2)

Feeder unit is installed at the headland on a special stand. Then the transmission pipeline made of rubber hoses with the nozzles is laid between the rows of plants. The distance between the rubber irrigation pipe is equal to the line distance of the plants. The injection irrigation of each plant starts at the time of the first watering. Our experiments showed that by this timepoint, for example, corn plants acquire height of $40-50 \mathrm{~cm}$ and have a distinct root system. Until this time, i.e., before laying pipes, all agrotechnical measures should be completed. These include chemical treatment, weed control, cultivation, tillage, etc. Before starting injection irrigation one should properly adjust feeder unit.

The feeder unit consists of a reservoir 1 (Fig.3), mounted on the stand 2 and irrigation tank 3 . The reservoir 1 has a pouring hole 4 with sealed cover 5 , which is provided with a flexible connecting pipe 6 and the air tube 7, whose lower ends are placed into the irrigation tank 3 .

The air tube 7 is made of a flexible material and is free to be moved in a vertical direction up and down. It is mounted on guides 8. Irrigation tank 3 is connected with the system pipeline 9, provided with a plug 10 . The lower end of the air tube 7 can change its position from the level $\mathrm{V}_{1}$ to $\mathrm{V}_{2}$, while the operating water level will change accordingly from $h_{1}$ to $h_{2}$. In any position of the lower end of the air tube 7 operating water level $h_{1}$ will vary within the narrow range ä. Before adjusting feeder unit the lower end of the air tube 7 should be in the lower position at the level of $\mathrm{V}_{1}$. To start the system, we open the cover 5 to fill the water tank 1 with an aqueous solution of nutrients. At that, the solution, when flowing through the flexible connecting pipe 6 , the irrigation tank 3 , and the system pipeline 9 , fills the pipe network of the irrigation system. Adjusting the flow of aqueous solution into the reservoir, it should be closed with a cover 5 ensuring the operating level of water in the irrigation tank at the level of $h_{1}$.

This level provides a necessary pressure head for the operating system to meet the water demand of plants in the initial phase of development. As far as the plant consumes a certain amount of water, the water level $h_{1}$ in the irrigation tank 3 will drop down to the level $\mathrm{V}_{1}$. At that, the variation in water level will occur within a 
narrow range of ä, which will not affect the operation mode of the irrigation system. Reduction of the vacuum in water tank 1 occurs through the air tube 7. As a result, portion of water from the reservoir flows through the connecting pipe 6 into the irrigation tank 3 , raising the water level up to $h_{1}$. At that, the access of air to the air tube 7 is terminated. Vacuum, established in the reservoir, maintains equilibrium in the feeder unit at a different (lower) level of water. The water is brought to the field by water carrier and poured into the reservoir.

Further, the above described process will be repeated. According to schedule, operation staff, when maintaining the system will charge the reservoirs with water. To do this, one must close the connecting pipe 6 , putting it on the plug 10 , and open cover 5. After filling the reservoir, he should close the cover 5 and open and the connecting pipe 6 . At that, the process of watering will be continued.

At variations of the plants' daily water use, depending on weather conditions and development phase, the water supply in accordance to the watering schedule, is ensured by the movement of air tube in the vertical direction (up or down) and its fastening at the desired level. Thus, one can set the required pressure head in the irrigation system, providing requirement of plants in water at the current phase of development.

Injection irrigation method was used in Zhambyl and Almaty regions.

Studies on irrigation regimes of tomato were conducted in 3 options: contour ditch irrigation, drip irrigation, and injection irrigation.

Field experiments were carried out in three options as well:

a) Option \# 1 - contour ditch irrigation (control);

b) Option \# 2 - non-ramming drip irrigation;

c) Option \#3 - injection irrigation.

The area of one plot was $28 \mathrm{~m}^{2}(1.4 \times 20 \mathrm{~m})$.

Experiments were done in 3-fold replication. The plots were separated by a protective strip $1 \mathrm{~m}$ in width. The following irrigation indicators were studied: use of irrigation water, duration of irrigation, soil moisture variation in time, total and average daily water use of tomatoes, irrigation depths and irrigation control.

The fertility and water-physical properties of the soil at the experimental plot were determined. The fertility of the soil was determined in the laboratory. Soil samples were taken from the layers at the depths of $0-20,20-40,40-60,60-80$, and 80$100 \mathrm{~cm}$. Minimum moisture-holding capacity (MM) and water penetration capacity (PC) were determined by flood frames technique. To do this, the area of $1 \mathrm{~m}^{2}$ was chosen. The prepared protected strip was supplied with water in the amount, which was necessary for complete saturation of the soil to the design depth. To calculate necessary water volume one should know available water reserve in the given soil layer and the total porosity of the layer.

To determine the fertility of the soil and salt composition, a test pit was installed to the depth of $1.2 \mathrm{~m}$. From the shadow side of the pit at the horizons of $0-10$ and $10-20 \mathrm{~cm}$ to $1 \mathrm{~m}$ soil samples were collected $(1-2 \mathrm{~kg})$ into the labeled bag and sent to the laboratory.

All types of agrotechnical operations, such as processing, weeding, thinning, and fertilizing were carried out.

Soil moisture was determined by thermostatic weight method. Soil samples were collected from the horizons of 0-10, 10-20, 20-30, $30-40,40-60,60-80$, and $80-100 \mathrm{~cm}$ in 3 -fold repetition.

The amount of water delivered to the plots was measured separately through the spillway in the $1^{\text {st }}$ option, and by elevation head in the vessel in the $2^{\text {nd }}$ and $3^{\text {rd }}$ options.

The elevation of the feeder unit was detected by visual observations. The elevation was chosen based on the requirement of water non flow out of the injection needle, ensuring the drippers flow rate within the range 1.1-1.3 1/h.

The total water use at drip irrigation is determined by the formula:

$\mathrm{E}_{0}=0.0006(25+\mathrm{t})^{2}(100-\mathrm{a}) ; \mathrm{m}^{3} /$ ha day

where $\mathrm{t}-\mathrm{is}$ the average daily air temperature, $\mathrm{C}^{0}$;

$\mathrm{a}-$ is the average daily air humidity, $\%$.

The average daily water use is determined by the formula:

$\mathrm{E}=\mathrm{E}_{0} \times \kappa_{\mathrm{b}} \times \kappa_{\mathrm{o}}, \mathrm{m}^{3} / \mathrm{ha}$,

where, $\mathrm{K}_{\mathrm{b}}$ - is bioclimatic coefficient;

$$
\mathrm{K} y=\frac{1}{1+(1-f)} ; \quad f=\frac{S}{F} ;
$$

where $\mathrm{S}$ - is the area of the local hydration 
per 1 ha, $\mathrm{m}^{2}$;

$\mathrm{F}-$ is the area of 1 ha equal to $10,000 \mathrm{~m}^{2}$; $\mathrm{S}=\mathrm{C}^{*} \mathrm{~N}$, where $\mathrm{N}-$ is the number of plants per 1 ha;

$$
\mathrm{C}-\text { is the area of humidification }
$$

contour under single tomato bush, $\mathrm{m} 2$

Irrigation depth for the control option is defined by the formula:

$$
\mathrm{m}=100 \mathrm{H} \gamma(\mathrm{MM}-\beta \mathrm{o}), \mathrm{m}^{3} / \mathrm{ha}
$$

where, $\mathrm{H}-$ is the hydration depth of $0.5 \mathrm{~m}$;

$\gamma-$ is the weight by volume, $\mathrm{t} / \mathrm{m}^{3}$;

$\mathrm{MM}$ - is the minimum moisture-holding capacity, $\%$;

$\beta o-$ is the pre-irrigation soil moisture, $\%$.

The hydration spacing under a single drip emitter is determined according to the formula:

$$
\mathrm{F}=\frac{\pi D^{2}}{4}, \mathrm{~m}^{2}
$$

where, $\mathrm{D}-$ is the wetted diameter, $\mathrm{m}$

The volume of the wetted layer:

$$
\mathrm{V}=\frac{\pi D^{2} h}{4}, \mathrm{~m}^{3}
$$

where $\mathrm{h}-$ is the wetted depth of $0.5 \mathrm{~m}$.

Irrigation depth per one tomato bush:

$$
\mathrm{m}=\frac{V(M M-\beta o)}{100}, \mathrm{~m}^{3},
$$

The duration of irrigation interval:

$$
T=\frac{m}{E o}, \text { days }
$$

The number of irrigations was determined by the formula:

$$
\mathrm{N}=\frac{\Pi}{T} \text { irrigations }
$$

where, $\Pi-$ is the number of days in the month.

At the injection irrigation (option 3)

\begin{tabular}{|c|c|c|c|c|c|}
\hline \multirow[t]{2}{*}{ Date } & \multirow{2}{*}{$\begin{array}{c}\text { Lowering the } \\
\text { water level in } \\
\text { the tank, } \\
\mathrm{cm}\end{array}$} & \multirow{2}{*}{$\begin{array}{c}\text { The volume of } \\
\text { water consumed } \\
\text { in accordance } \\
\text { with the scale, } \\
\text { liters }\end{array}$} & \multirow{2}{*}{$\begin{array}{c}\text { The volume of } \\
\text { water supplied } \\
\text { per cycle, } \\
\text { liters }\end{array}$} & \multicolumn{2}{|c|}{ The average daily water use } \\
\hline & & & & $\begin{array}{c}\text { Per } 100 \text { pieces } \\
\text { of seedlings, } \\
\text { liters/day }\end{array}$ & $\begin{array}{l}\text { Per } 1 \text { ha } \\
\mathrm{m}^{3} / \text { day }\end{array}$ \\
\hline 1 & 2 & 3 & 4 & 5 & 6 \\
\hline $5^{\text {th }}$ of May & - & - & - & & \\
\hline $15^{\text {th }}$ of May & 35 & 35 & 35 & & \\
\hline $25^{\text {th }}$ of May & 55 & 55 & 90 & 5.6 & 2.0 \\
\hline \multirow[t]{2}{*}{$31^{\text {st }}$ of May } & 60 & 60 & 150 & & \\
\hline & Tota & l water supply in May: & 150 liters & & \\
\hline $10^{\text {th }}$ of June & 70 & 70 & 70 & & \\
\hline $20^{\text {th }}$ of June & 90 & 90 & 160 & 8.3 & 2.96 \\
\hline \multirow[t]{2}{*}{$30^{\text {th }}$ of June } & 90 & 90 & 250 & & \\
\hline & Tot: & al water supply in June: & 250 liters & & \\
\hline $10^{\text {th }}$ of July & 80 & 80 & 80 & & \\
\hline $20^{\text {th }}$ of July & 100 & 100 & 180 & 9.3 & 3.3 \\
\hline \multirow[t]{2}{*}{$31^{\text {st }}$ of July } & 100 & 100 & 280 & & \\
\hline & Tot & al water supply in July: & 280 liters & & \\
\hline $10^{\text {th }}$ of August & 70 & 70 & 70 & & \\
\hline $20^{\text {th }}$ of August & 90 & 90 & 160 & 7.8 & 2.8 \\
\hline \multirow[t]{3}{*}{$31^{\text {st }}$ of August } & 85 & 85 & 245 & & \\
\hline & Total & water supply in August: & 245 liters & & \\
\hline & & Total water supply: & 925 liters & & \\
\hline
\end{tabular}
irrigated water was pumped directly into the xylem of the plants by means of injection needles. Water was continuously flowing into the plant in accordance with its need; therefore here we do not have to control the irrigation terms.

Table 1 . Metering of water supply at injection irrigation (2012)

*Note: The tank capacity is 100 liters, the height of the water in the tank is $100 \mathrm{~cm}$. Each layer of water $1 \mathrm{~cm}$ thick corresponds to one liter. 


\section{RESULTS}

Metering of irrigation water was carried out on the calibration scale of the feeder unit. During the growing season 100 tomato plants consumed 1015 liters of water. At that, in May of 2012 during the injection irrigation 925 liters of water were consumed, while in 2013 - 1015 liters. At that, during the injection irrigation in May of 2013, 150-166 liters of water were consumed, while in June - 267 liters, in July - 311 liters, and in August - 271 liters. Irrigation water requirement during the growing season of tomatoes per 1 hectare amounted for $383 \mathrm{~m}^{3} / \mathrm{ha}$ (Tables 1 and 2).

Comparing data of 3 options, it should be noted that at drip irrigation (option 2) saving of irrigation water in comparison with contour ditch irrigation (option 1) amounts for $23.5 \%$, whereas at the injection irrigation (option 3 ) - saving is $92 \%$ (Table 3).

When analyzing the experimental data, especially those for new irrigation methods, such as drip irrigation and injection irrigation, the irrigation water use (IWU) needed to produce one

Table 2 . Metering of water supply at injection irrigation, option 3 (2012)

\begin{tabular}{|c|c|c|c|c|c|}
\hline \multirow[t]{2}{*}{ Date } & \multirow{2}{*}{$\begin{array}{c}\text { Lowering the } \\
\text { water level in } \\
\text { the tank, } \\
\mathrm{cm}\end{array}$} & \multirow{2}{*}{$\begin{array}{l}\text { The volume of } \\
\text { water consumed } \\
\text { in accordance } \\
\text { with the scale, liters }\end{array}$} & \multirow{2}{*}{$\begin{array}{c}\text { The volume of } \\
\text { water supplied } \\
\text { per cycle, } \\
\text { liters }\end{array}$} & \multicolumn{2}{|c|}{ The average daily water use } \\
\hline & & & & $\begin{array}{c}\text { Per } 100 \text { pieces } \\
\text { of seedlings, } \\
\text { liters/day }\end{array}$ & $\begin{array}{c}\text { Per } 1 \text { ha, } \\
\mathrm{m}^{3} / \text { day }\end{array}$ \\
\hline 1 & 2 & 3 & 4 & 5 & 6 \\
\hline $5^{\text {th }}$ of May & - & - & - & & \\
\hline $15^{\text {th }}$ of May & 35 & 35 & 35 & & \\
\hline $25^{\text {th }}$ of May & 61 & 61 & 96 & 5.3 & 18.8 \\
\hline $31^{\text {st }}$ of May & 70 & 70 & 166 & & \\
\hline \multicolumn{6}{|c|}{ Total water supply in May:166 liters or $69.3 \mathrm{~m}^{3} / \mathrm{ha}$} \\
\hline $10^{\text {th }}$ of June & 70 & 70 & 70 & & \\
\hline $20^{\text {th }}$ of June & 85 & 85 & 155 & 8.9 & 32.8 \\
\hline $30^{\text {th }}$ of June & 112 & 112 & 267 & & \\
\hline \multicolumn{6}{|c|}{ Total water supply in June:267 liters or $95.4 \mathrm{~m}^{3} / \mathrm{ha}$} \\
\hline $10^{\text {th }}$ of July & 85 & 85 & 85 & & \\
\hline $20^{\text {th }}$ of July & 110 & 110 & 195 & 9.0 & 3.2 \\
\hline $31^{\text {st }}$ of July & 116 & 116 & 311 & & \\
\hline \multicolumn{6}{|c|}{ Total water supply in July:311 liters or $121 \mathrm{~m}^{3} / \mathrm{ha}$} \\
\hline $10^{\text {th }}$ of August & 82 & 82 & 82 & & \\
\hline $20^{\text {th }}$ of August & 95 & 95 & 177 & 7.9 & 2.8 \\
\hline $31^{\text {st }}$ of August & 94 & 94 & 271 & & \\
\hline
\end{tabular}

*Note: The tank capacity is 100 liters, the height of the water in the tank is $100 \mathrm{~cm}$.Each layer of water $1 \mathrm{~cm}$ thick corresponds to one liter.

Table 3. Comparison between options 1 and 2 (2012/2013)

\begin{tabular}{lcccc}
\hline Experimental options & $\begin{array}{c}\text { The average } \\
\text { yield from one } \\
\text { bush,kg }\end{array}$ & $\begin{array}{c}\text { Number of } \\
\text { plants per ha }\end{array}$ & $\begin{array}{c}\text { Average yield, } \\
\mathrm{t} / \text { ha }\end{array}$ & $\begin{array}{c}\text { Increase } \\
\text { compared with } \\
\text { the control, } \mathrm{t} / \mathrm{ha}\end{array}$ \\
\hline Option 1: contour ditch irrigation (control); & $0.78 / 0.94$ & $35714 / 35714$ & $27.8 / 30.6$ & - \\
Option 2: non-ramming drip irrigation & $0.86 / 0.96$ & $35714 / 35714$ & $32.2 / 34.3$ & $4.4 / 3,1$ \\
Option 3: injection irrigation & $0.88 / 1.10$ & $35714 / 35714$ & $33.1 / 35.6$ & $5.2 / 5.0$ \\
\hline
\end{tabular}


Table 4. The efficiency of irrigation water use at different irrigation options of tomato plants for 2012/2013

\begin{tabular}{|c|c|c|}
\hline Experimental options & Indicators & $\begin{array}{l}\text { Data for 2012/ } \\
2013\end{array}$ \\
\hline \multirow[t]{3}{*}{$\begin{array}{l}\text { Option 1: contour ditch irrigation } \\
\text { (control); }\end{array}$} & $\begin{array}{l}\text { Irrigation water requirement, } \mathrm{m}^{3} / \text { ha for output } \\
\text { yield, } \mathrm{t} / \mathrm{ha} \text {; }\end{array}$ & $4570 / 4710$ \\
\hline & The use of irrigation water for production of a & $27.8 / 30.6$ \\
\hline & unit of output yield, $\mathrm{m}^{3} / \mathrm{t}$ & $165 / 154$ \\
\hline \multirow[t]{3}{*}{ Option 2: non-ramming drip irrigation } & $\begin{array}{l}\text { Irrigation water requirement, } \mathrm{m}^{3} / \mathrm{ha} \text { for output } \\
\text { yield, } \mathrm{t} / \mathrm{ha} \text {; }\end{array}$ & $2763 / 3070$ \\
\hline & The use of irrigation water for production of a & $32.2 / 34.3$ \\
\hline & unit of output yield, $\mathrm{m}^{3} / \mathrm{t}$ & $86 / 87$ \\
\hline \multirow[t]{3}{*}{ Option 3: injection irrigation } & $\begin{array}{l}\text { Irrigation water requirement, } \mathrm{m}^{3} / \mathrm{ha} \text { for output } \\
\text { yield, } \mathrm{t} / \mathrm{ha} \text {; }\end{array}$ & $330 / 383$ \\
\hline & The use of irrigation water for production of a & $33.1 / 35.6$ \\
\hline & unit of output yield, $\mathrm{m}^{3} / \mathrm{t}$ & $10.0 / 10.8$ \\
\hline
\end{tabular}

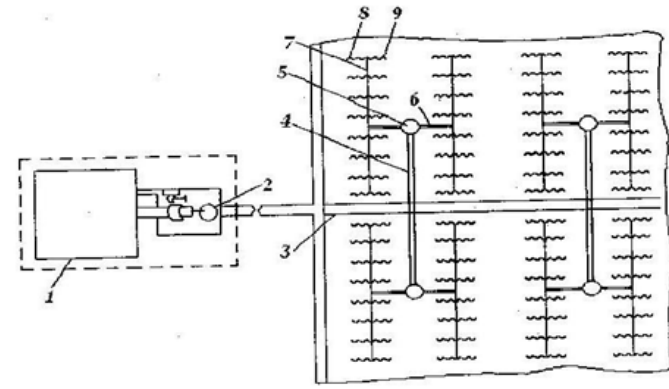

1- water tank, 2 - feeder unit, 3,4,6 and 7 - rubber pipes, 5 - water timer; 8,9 - boom with needles;

Fig. 1. The exemplary diagram of the injection irrigation system

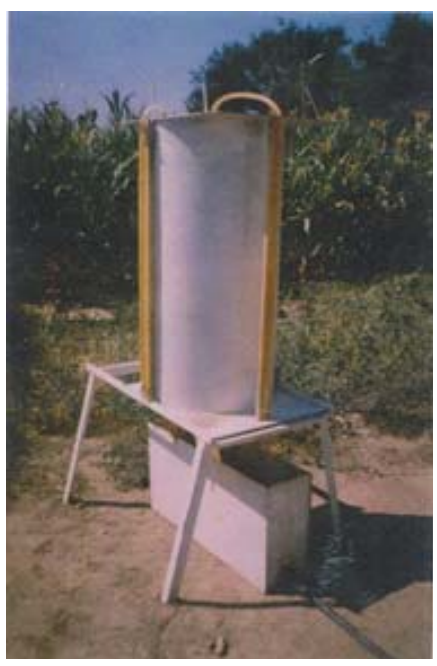

Fig. 2. Feeder unit for injection irrigation ton of commercial product, is of particular interest $\mathrm{t}^{17}$ 18 .

The materials of our own studies show that the injection irrigation method (option 3) provides a high yield with minimum use of irrigation water, i.e. IWU is by $76.2 \mathrm{~m}^{3}$ per hundredweight less than that for non-ramming drip irrigation, and by $14.2 \mathrm{~m}^{3}$ per hundredweight less than for contour ditch irrigation (Table 4).

Therefore, at injection madefaction the irrigation water is used more efficiently than at surface and drip irrigation techniques. This is

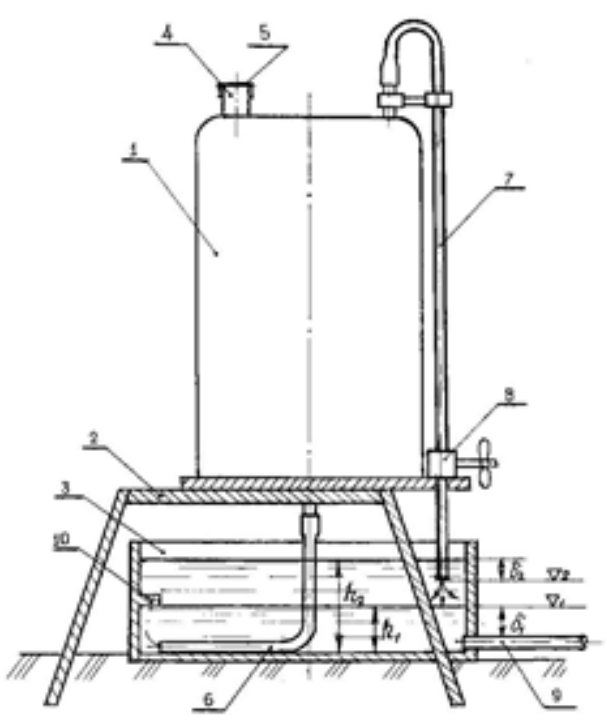

Fig. 3. Controls of injection irrigation system with feeder unit A.S. \#40796 
because at the surface madefaction a huge amount of the pumped water evaporates from the soil, while at the injection irrigation the water supplied into the xylem is not subjected to physical evaporation, since it is completely used through the transpiration.

\section{CONCLUSIONS}

Thus, the water regime of plants, both at the injection and conventional irrigation methods are governed by the general laws of nature. But while at the conventional irrigation the supplied water is spent on physical evaporation, transpiration and infiltration, at the injection irrigation it is spent only on transpiration. This is the method to save irrigation water. Besides testing the injection irrigation on tomato plants this method was tested also on watering of corn in different climatic zones ${ }^{19,20}$.

Table 5 shows the main indicators of the five-year pilot study of maize for silage watering applying surface and injection irrigation methods. These data also indicate high productivity of injection irrigation.

\section{REFERENCES}

1. Zubairov, O.Z., "New methods of irrigation," Water Management of Kazakhstan. Astana, 2004; 2: 26-30.

2. Zubairov, O.Z., Tatibaev, A.A., Konstantinov, V., "Injection Irrigation System for Watering Plants," provisional application \#10256, bulletin 6 of 15.06.2001, 2001.

3. Zubairov, O.Z., Ismailova, G.K., "Injection Irrigation System," Proceedings of the Kazakh National Agrarian University: Research and Results, Almaty, 2002; 47: 13-15.

4. Varisova, N.N., and Shustova, L.A., "Physiology of Plants," Kolos, Moscow, 1969; 48-49.

5. Diietrich, W., Ulrich, P., "Zur Entwicklungg von Unberboden nach Gefugemeliration," Archiv fur Ackeu und Piianbau und Bodenkunde, 1979; 23(12): 721-732.

6. Karmanov, V.G., and Radchenko, S.S., "On Water Metabolism of Plants and the Mode of its Autonomic Control", Irrigation Regime of Agricultural Crops. Kolos, Moscow, 1965; 199203.

7. Duke, G.V., "Comparative Experiments with
Flield Crops," London, 1974; 211.

8. Tattibaev, A.A., Kozhanov, K.Sh., "Improving Surface Irrigation," Proceedings of the International Scientific and Technical Conference "Water resources: Environmental aspects and their use", Zhambyl, 1996; 60-61.

9. Zubairov, O.Z., and Tleukulov, A.T., "Irrigation of Tomatoes by Low-pressure Drip System in Zhambyl Region," Research and Results, Kazakh National Agricultural University, Almaty, 2008; 1: 111-113.

10. Norum, D.J et al., "Acclimation of System Optimal Depth," Concept-Journal of the Irrigation and Drainage Division. Proceedings of the ASAE, 1979.

11. Kutch, H., and Schuh, H., "Versuschder Mathematischen Darstellungg der Wasserbedafsh-Ocffisient fur Bewasserte," Kulturen-Zeitschut fur Bewasserung Swirtshaft, 1980; 183-191.

12. Elson, A., "In-house Manure Drying," Poultry Industry, 1973; 37: 14-15.

13. Rong-jiang Yao, Jing-song Yang, Tong-juan Zhang, Li-zhou Hong, Mao-wen Wang, Shi-peng Yu, Xiang-ping Wang, "Studies on Soil Water and Salt Balances, and Scenarios Simulation Using SaltMod in a Coastal Reclaimed Farming Area of Eastern China," Agricultural Water Management, 2014; 131: 115-123.

14. Le Blanc, D., "Molten Salt Reactors: A new Beginning for an Old Idea," Nuclear Engineering and Design, 2010; 240(6): 1644-1656.

15. Le Blanc, D., "The Influence of Salt Stress on ABA and Auxin Concentrations in Two Maize Cultivars Differing in Salt Resistance," Journal of Plant Physiology, 2013; 170(2): 220-224.

16. Zörb, Ch., Geilfus, Ch.-M., Mühling, K.H., and Ludwig-Müller, J., "The Influence of Salt Stress on ABA and Auxin ...," Journal of Applied Botany and Food Quality, 2014; 85: 23-33.

17. Dukhovny, V.A., and Horst, M.G., "Surface Irrigation Technique in the Arid Zone due to the Development of Irrigation Systems," Scientific Works of SANIIRI, Tashkent, 1984; 172.

18. Kalashnikov, A.A., Konstantinov, A.V., and Zharkov, V.A., "Implementation of ResourceSaving Irrigation Technologies in Fruit Nurseries," Complex Reconstruction of Irrigation Systems of Kazakhstan, Tashkent, 1988; 142-151.

19. Suyumbayev, D.A., Atakanov, A.Zh., and Kulov M.K., "Drip Irrigation and the Prospects of its Application in the Kyrgyz SSR, Overview," Kirgiz Center for Scientific and Technical Information, Frunze, 1982; 69. 
20. "Guidance on the Design, Construction and Operation of Drip Irrigation Systems," Soyuzvodproekt, Moscow, 1981; 180.

21. "Calculation of Economic Efficiency of Scientific-Research and Experimental-Design
Works in the Field of Land Reclamation and Water Management," Methodical Recommendations, Taraz, 2001; 2 p. 